\title{
2. 現状の問題点と将来への展望
}

\author{
山本 裕 康 \\ 厚木市立病院内科
}

\section{はじめに}

腎代替治療は，腎機能が廃絶した末期腎不全に対す る治療であり，わが国においては慢性血液透析療法 (hemodialysis : HD) がその大多数を占めている. 黎 明期における HD の治療目的は救命であったが，透析 医学の進歩に伴って社会復帰を目指すようになり，今 日では長期生存も可能になった。 その結果, 患者の社 会活動を支援することを目的とする更生医療であると ともに, 延命療法の側面をも有するようになっている. わが国の透析患者数は年々増加しており，2011 年末 で 304,592 人とついに 30 万人を超え, 一時減少して いた新規透析導入患者数も 2011 年には再び増加に転 じ， 38,893 人と過去最多であった ${ }^{1)}$. その一方，新規 透析導入患者の高龄化と糖尿病の増加は相変わらず顕 著であり，導入時点ですでに脳血管障害を有する症例 や，悪性腫瘍あるいは長期透析に伴う合併症など多様 な病態にある患者が増加している。このような状況に あるものの，わが国の HD の治療成績は諸外国とくら べて良好であるが，透析患者の年間死亡数は毎年増加 しており，2011 年は 30,831 人にのぼり，過去 20 年ほ ど $9 \%$ 台に留まっていた年次別粗死亡率はついに $10 \%$ を超えた.この傾向は今後も続くものと推察される. また，新規導入された年に死亡した患者の死亡原因を みると， 2011 年では第 1 位 ; 心不全 $(25.4 \%)$ ，第 2 位 ; 感染症 $(24.4 \%)$, 第 3 位 ; 悪性腫瘍 $(11.6 \%)$, 第 4 位 ; 脳血管障害 $(5.3 \%)$ であった。 心不全や感染 症が上位を占めるのは全身状態を反映したものと思わ れるが，導入後 1 年以内に悪性腫瘍で死亡する患者が $11 \%$ 以上という現実は注目すべきであろう。これは， 相当数の患者が導入時に悪性腫瘍に罹患していた可能 性を示唆するとともに，終末期医療の在り方や HD の 意義について考えることの重要性を指摘しているよう にも思う。
HD は，間欠的な体外循環を要する血液浄化療法で あるため，循環動態への負荷は否めない，重篤な心血 管系疾患に罹患した患者や，全身状態の不良な高齢者 に対して HD を施行すると，生命予後を一気に悪化さ せる危険性すらある。このような状況は，新規導入患 者のみならず長期維持透析患者でも生じ得る。その対 応として腹膜透析の適応などを検討することになる が，困難な場合には HDへの導入あるいは治療継続を 断念せざるをえない.このような医学的根拠に基づい た判断は容認されるであろうが，循環動態の悪化や悪 性腫瘍以外にも，終末期医療に準じた対応を要する症 例に遭遇し, HD 導入や治療継続の判断に苦慮するこ とも稀でなく, 今後さらに増加するものと思われる. 多くの医療者が悩んできた HD の導入あるいは継続 を見合わせるという命題に対するひとつの考え方とし て，今回の提言(案)が示されたことは大きな意味を持 つものと思う。 その一方, 解決しなければならない課 題も存在する。本稿では, わが国の現状での問題点を 考察し, 将来への展望に繋げたい.

\section{I . 提言(案)の要点}

今回示された提言(案)は，次の四つにより構成され ている.

提言 1 : 情報提供と自己決定の援助

・患者に十分な情報を提供する.

・患者から十分な情報を収集する.

・患者が意思決定した過程を理解する。

提言 2 : 自己決定の尊重

・患者に事前指示書の作成を勧める.

提言 3 : 同意書の取得

・慢性血液透析療法の導入前に同意を取得する.

提言 4 : 医療チームによる慢性血液透析療法の見合わ せ

・一定の状況を満たす終末期患者では，透析療法の導

山本 裕康 厚木市立病院内科 $\overline{\mathrm{T}} 243-8588$ 神奈川県厚木市水引 1-16-36

Hiroyasu Yamamoto Tel : 046-221-1570 Fax : 046-222-7836 
入または継続を見合わせる.

・患者の意思を尊重した事前ケア計画を策定する.

・患者に効果的な緩和ケアを提供する.

医療行為を実施する際には, 十分な情報提供を行い, 患者の同意を得たうえで行うことが基本となる，HD は，体外循環を要し，患者に相応の負担が掛かる介入 的治療であることから, 多くの施設で導入時に治療開 始についての同意を取得している。 しかし，今回の提 言では, HD が延命治療としての側面も有することか ら，導入のみならず継続の見合わせについて検討しな ければならない状況を迎えることを念頭におき，患者 および家族に対して事前に十分な情報提供を行い，そ れを理解してもらえるよう援助し, 患者に対しては自 己決定を事前指示書として記すことを勧めている。 ま た，患者自身での判断が困難あるいは意思表示が困難 な場合などでは，どのように医療およびケアの方針を 決定すべきかについて，患者家族との関係を含めて示 している.

ここに記されたプロセスを経ることで，HDの導入 あるいは継続を見合わせる判断が適正になされること を期待している，その一方，生命の終焉を意味する導 入あるいは継続の見合わせに関して，患者の意思決定 が適切になされることは容易ではないと思われる。ま た，現在のわが国の医療体制を考えたとき，提言で示 されたプロセスを遂行するにはいくつかの課題がある ものと考える.

\section{II . 提言(案)の課題：現況と対比して}

\section{1.『情報提供と自己決定の援助』のタイミングにつ いて}

患者および家族に対して導入あるいは継続を見合わ せるという選択肢に関する情報提供をするタイミング は，医療者側がその検討が必要な状況に直面した場合 と, 全身状態は安定しているが将来的な事態を仮定し 事前指示として患者および家族の見解を求めておこう と考える場合，に大別できるのではなかろうか. 前者 では，全身状態が不良となった患者自身に厳しい選択 を迫ることになり，また，多くはその選択の意味を理 解することが困難になっている可能性が高い. した がって，家族への情報提供を行いその意向を確認する ことが主体となろう。後者では, 切迫した状況ではな く一般論として患者自身の終末期医療に対する考え方 を確認する意味合いが強く，事前指示書を作成しても らうことは可能である. この情報提供のタイミングだ
が，その候補として透析導入時に行うことが想定され る.しかし，その際に患者はこれを受入れることがで きるだろうか. 多くの慢性腎臓病患者は, 透析を回避 するため懸命に保存的治療を継続しており，末期腎不 全に至り透析療法を開始するという事態を受容するの が精一杯で, 最終的に訪れる死についてまで考え, 自 らの結論を導き出してもらうことは，ごく一部を除い て難しいように感ずる. 安定した維持透析を行えるよ うになった時期に，患者自身の意向を確認するほうが 精神的負担は軽減されるかもしれない，導入施設より も患者や家族に接する時間が長い維持透析施設におい て，将来の導入あるいは継続の見合わせに関する情報 提供を行い, 患者や家族の意思を確認することもひと つの対応策であろう。いずれにしても，患者と医療者 との信頼関係が確立していることが，この情報提供を 行う大前提であろう.

\section{2.『自己決定の尊重』と事前指示書の取り扱い}

事前指示書は, 意思決定不能状態に陥った場合に, どのように終末期医療を行って欲しいかを，健康な時 期に意思表明したものであり，欧米諸国においては法 的にも尊重されている。しかし，わが国における事前 指示(書)の取り扱いは明確でない。これは, 健康な時 期に意思表明した終末期医療に対する漠然とした抽象 的な考え方が，実際の末期状態に直面した場合と必ず しも合致しないのではないかという疑問のためであ り, 事前指示 (書)に従って行った医療行為であっても, 違法と判断される可能性を含んでいる. 最近, 多くの 学会から終末期医療における指針等が示されている が，選択した治療に対する法的な担保をもとめる声が 高まっている. それを受け, 超党派の国会議員で組織 された『尊厳死法制化を考える議員連盟』から「終末 期の医療における患者の意思の尊重に関する法律案 (仮称)」が公表された。 これは，終末期にある患者の 意思を尊重するために，延命措置に関する意思決定が できることを法律で定めるとともに，法律が定める条 件に合致した対応をした医師を免責することが目的で ある。現在，1）延命措置を開始しない場合（不開始） のみを対象とする案と, 2) 現在継続中の延命治療を中 止した場合も含める案の二つが検討中である．患者の 自己決定を尊重することは医療の根幹に関わることで あり，終末期医療において適正で尊厳ある判断がなさ れるよう，迅速な法的整備を望む。

\section{3.『医療チームによる慢性血液透析療法の見合わせ』 と医療体制}

事前指示書を含めた患者の意思および家族の意思と して，HDの導入/継続の見合わせを望んだ場合，医療 
者はどのように対応すべきであろうか. 今回の提言 (案)では，担当医が単独で判断し実施することは容認 しておらず，医療チームを編成し，複数の専門家から なる委員会の設置を提唱している.HD の導入/継続 の見合わせという結論に至ったプロセスを検証し，適 切な医療を実践するためには必要な対応と考える。 そ の一方, 当該患者の担当医療施設のみで，この対応が 完結できるかという疑問が生じる. 本学会に登録して いる透析施設数は 4,200 以上であるが，その多くは 1 名ないし数名の常勤医により運営されていると思わ れ，当該患者以外の診療を考えると提言(案)にある体 制を構築するのは容易ではなからう。そこで地域基幹 病院との連携が必要となるが，その多くが急性期病院 としての役割を担っていることから，終末期医療への 対応にも限界がある。すでに述べたように，導入患者 の高齢化と糖尿病の増加は著しく, 年間死亡者数 3 万 人以上, 粗死亡率 $10 \%$ 以上という現状を勘案すると, 地域基幹病院とは別の組織との連携が望まれる。例え ば，同一地域にある複数の医療施設が合同で導入/継 続の見合わせに関わる医療チームや専門委員会を編成 する，あるいは日本透析医学会に専門委員会を設置し 委ねる，などの対応策があげられよう。しかし，患者 や家族に関する情報が適切に提供され，適正な判断が なされるためにはいくつもの課題が残るように思う.

\section{おわりに}

人々は自らの生命について考え，いつかは必ず訪れ る死に対して準備することの大切さを理解している. しかし，実際にこの命題について熟考し，自らの意思 を明確に表明できる方はそれほど多くないのではない だろうか. 自分らしく生きて行くことについては考え るものの，どのような状態になったら現代医療の恩恵 を享受せず，そのまま自然な死を迎えようかというこ とについて結論をだすことは容易ではない，近年，終
末期医療のあり方について，厚生労働省をはじめさま ざまな学会からガイドライン等が示された ${ }^{225)}$.いず れもが臨床現場の抱える問題と対峙し, 適正な医療が 実践されるように，一定の基準あるいは考える筋道を 示したものであり，今後もこのような議論が盛んにな るだろう。

HD の導入および継続の見合わせは，終末期医療に おける透析療法の在り方自体を考える必要があろう.

しかし，終末期医療には，基礎疾患そのものに対する 治療に加え，精神的ケアや疼痛対策，さらには栄養管 理・呼吸管理・循環動態管理・家族へのサポートなど, 多くの診療行為が包括されて打り，透析療法はそのな かの一部にすぎない，導入および継続の見合わせを議 論しなければならない患者が, どのようにしてその終 焉を迎えるのかは，これらの医療行為をどのように組 み合わせ実施するかによって異なる。終末期医療の在 り方は，これらのさまざまな医療行為を総合的に評価 したうえで，治療方針を決定すべきことであり，透析 療法はその中のひとつであることを念頭においた慎重 な対応が望まれる。

\section{文献}

1）日本透析医学会：罒説わが国の慢性透析療法の現況 （2011 年末現在）http://www.jsdt.or.jp/overview_ confirm.html

2）厚生労働省：終末期医療の決定プロセスに関するガイ ドライン http://www.mhlw.go.jp/shingi/2007/05/dl/ s0521-11a.pdf

3）日本老年医学会「立場表明 2012」http://www.jpngeriat-soc.or.jp/tachiba/jgs-tachiba2012.pdf

4）日本救急医学会 救急医療における終末期医療に関す る提言（ガイドライン） 2007 http://www.jaam.jp/ html/info/info-20071116.pdf

5）全日本病院協会 終末期医療の指針 $2007 \mathrm{http}: / / \mathrm{www}$. ajha.or.jp/voice/pdf/071219_1.pdf 